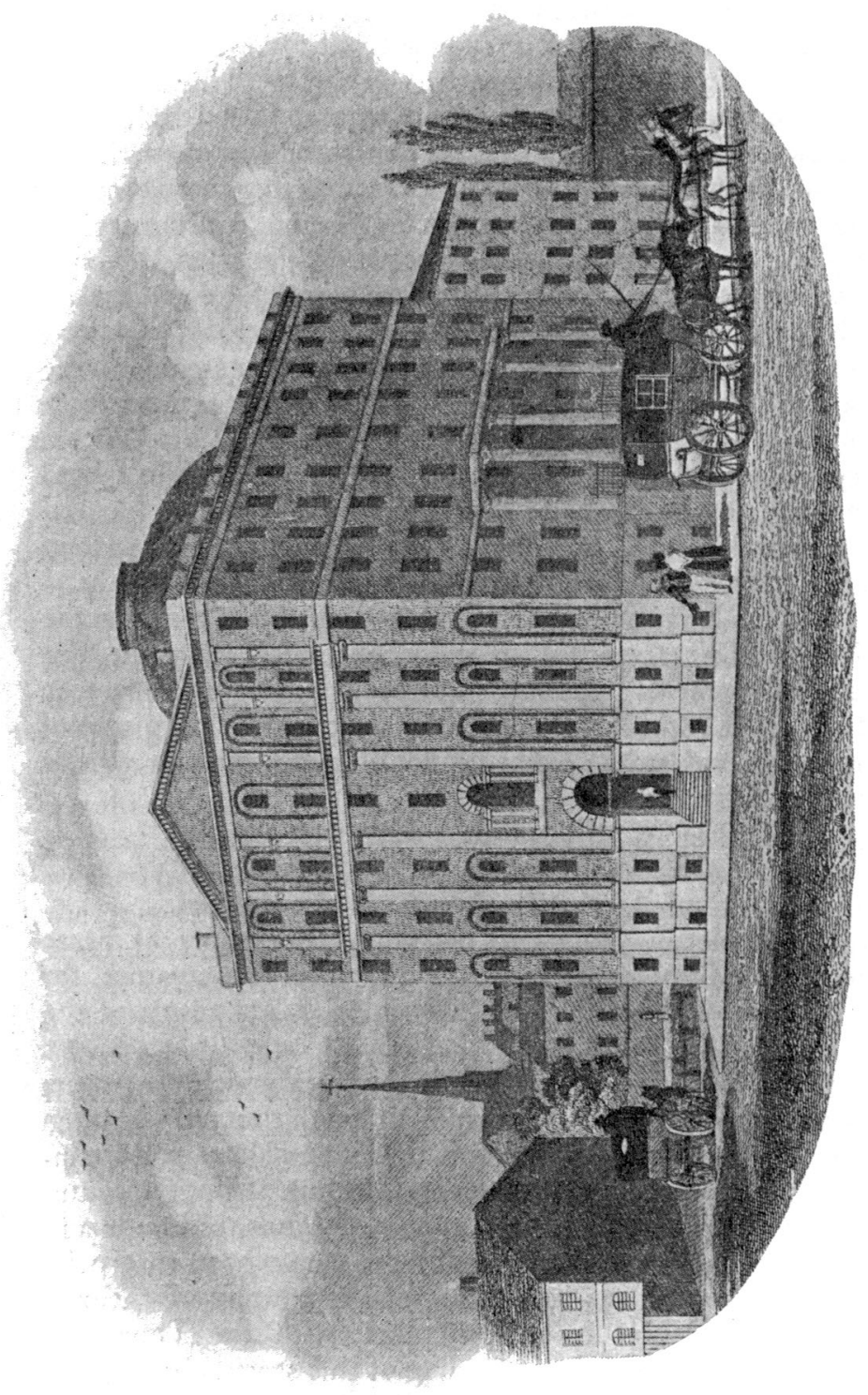

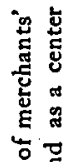

훙

옹

* डे

i

की .․ㅡㄹ

产

8 ؛

ब 5 \%

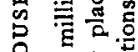

II

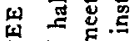

岩

댕정

(1) क क

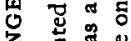

鹃

突 豆

$x$ 过

되 을 ․ㅗㅇ

z

원

点

$\infty$ 可.

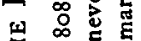

昰

政

苛

o

蛋点

궁

艼

过

을

웝

过

岕

鱼䞤 


\section{Business and the Coffee House}

An old ledger, which has come to the Society, belonging to the proprietor of the Boston Exchange Coffee House, recalls the part once played by taverns in social and commercial life. As the Mermaid Tavern was the meeting place of Shakespeare's circle, and the St. James Coffee House the convivial headquarters of the Whigs in the time of Queen Anne, the Exchange Coffee House was a rendezvous of the leaders of maritime Boston in the early part of the nineteenth century. The names over accounts in the ledger of John Jones, the proprietor, show that the patronage included statesmen like Daniel Webster, professional men like Harrison Gray Otis, and military men like General William H. Sumner, but the characteristic features of the house centered around shipping and merchant-shipowners, as did the activities of all New England. The leading merchants of the day, like Thomas Handasyd Perkins, Israel Thorndike, and William Sturgis and John Bryant of the Northwest fur trade, seem to have enjoyed the vintages from Mr. Jones' bar.

In fact, the original purpose in building the Coffee House was to provide appropriate facilities for the "genial institution of "Change."' This was a time-honored custom of the merchants to meet on the sidewalk of State Street at about one o'clock as they left their counting-rooms, and talk "shop, ships and politics" for half an hour or so. The whole first story of the ambitious new Coffee House was devoted to a great Exchange Floor, but this probably saw little business, for according to the contemporary account of Caleb Snow, the merchants preferred to follow in the way of their fathers, and meet more informally on State Street, "even in the inclement winter months."

But the tavern achieved a place in the commercial scheme of things in a number of other ways. No expense had been spared to provide every convenience for the merchants. The seven-story pile was surmounted by a dome which a periodical of the day describes as "elegant and spacious, ... I Ioo feet Io inches in circumference, the base protected by a handsome railing, within which is a seat and box, containing a perspective glass, used daily to ascertain the shipping entering the harbor."

Samuel Topliff's first News Room was located in the Exchange Coffee House, and in that way the tavern became for a time a unique commercial institution in Boston. The room was established by 
Samuel Gilbert, shortly after the house was built, in I 808 , but was soon taken over by Topliff, who may be called the forerunner of an associated press. It was through his correspondents that most of the foreign news was distributed to the Boston papers. He was the first to hear of a ship as she came within sight of the "telegraph" station in Boston harbor, and one of his rowboats collected the first news of foreign ports from the in-coming vessel.

This marine "telegraph" was an ingenious arrangement of semaphores, which had been used for signalling the approach of vessels from hill to hill, since the year eighteen hundred. A series of stations along the coast from Edgartown to Hull told Boston and Salem of the approach of vessels as soon as they entered Vineyard Haven.* Samuel Topliff's establishment erected one of these semaphores on Long Island, in Boston Harbor, which communicated with his house on Fort Hill. It consisted of a staff, ninetytwo feet high, with black painted balls, six feet in diameter suspended from a yard thirty feet long. The "telegraph" was not installed until after the departure of the News Room for Merchants' Hall, but Topliff's old quarters were taken up by a rival, and the Coffee House continued to be a center of marine information until 1842 , when the two reading rooms were united under a new management.

In these news rooms could be had the principal American papers, and foreign papers and price lists. Besides these, seven books were kept, in which current news, especially the sort that would be of interest to merchants; arrivals, in Boston and other ports; and clearances, were daily recorded. A merchant, writing a eulogy on Topliff's Reading Room at the time of its closing, is quoted as saying that it had become as much identified with the merchants of Boston as State Street itself. $\dagger$

Local journalists boasted that no other part of the country could show anything like the luxurious and tasteful Coffee Room, with its scarlet hangings and mahogany. Here merchant-shipowners met casually. And as Garraway's in London, which was celebrated as the haunt of "people of quality, who have business in the City, and the most considerable and wealthy citizens," was the scene of important mercantile transactions, the Coffee Room at the Exchange undoubtedly saw a great deal of business settled over the coffee cups or wine glasses.

* Samuel Eliot Morison, "Maritime History of Massachusetts."

† Ethel Stanwood Bolton, "Topliff's Travels." 
In the magnificent arched ball-room, converted for the occasion into a banqueting hall, Hull and Bainbridge were fêted after their brilliant naval exploits in the War of I812, Federalist Boston forgetting, in the victories of her beloved "Constitution," that the war was the iniquitous doing of Jefferson and his Jacobins, foisted upon the country for the express purpose of ruining New England commerce. The same room, gay with mirrors and chandeliers, and rich yellow and purple draperies, was the scene of the banquet celebrating the longed-for news of peace, the end of embargoes, and the comparative freedom of the seas for Massachusetts ships.

A considerable part of the building was let to various private concerns. Of these, Topliff's Merchants' Reading Room, which has been described earlier, was the most profitable for the tavern, for it made the practice of dropping in at the Exchange Coffee House a habit with the merchants. Other companies which were housed there included a bank which is now one of the prominent financial institutions of Boston, several insurance and brokerage firms, a fashionable tailor, a number of grocers, and a lottery office. Apropos of the last establishment, the same writer whose description of the dome is quoted above, remarks that the proprietors, after distributing so many prizes to individuals, seem to have drawn a blank themselves, having been jilted by the Goddess of Chance just as they were about to place her shrine in a roomier temple. The Coffee House was a losing venture from the beginning. It was built on too large a scale for the needs of its day. But though it was not itself a financial success, it held an important commercial rôle through Topliff's News Room and its successor, and the informal comings and goings of merchants, and saw the social reflection of one of the most eventful chapters in American commercial history.

\section{History in the Making}

ON April 10, I 928, the first complete periodical ever sent over the telephone wires was issued by a Cambridge firm. A single printed master copy was sent to the New York office of the American Telephone and Telegraph Company, and transmitted by telephotography to a Boston printer. A few hours later, the April issue of the "Industrial Bulletin of Arthur D. Little, Inc." was distributed from Boston. Does this perchance foreshadow the publication of a national or international morning journal? 